ZOOLOGIA 27 (5): 732-740, October, 2010

doi: $10.1590 /$ S1984-46702010000500010

\title{
Influence of the river flow on the structure of fish assemblage along the longitudinal gradient from river to reservoir
}

\author{
Alex Braz lacone Santos ${ }^{1}$; Bianca de Freitas Terraํํ \& Francisco Gerson Araújo ${ }^{1,2}$ \\ ${ }^{1}$ Laboratório de Ecologia de Peixes, Universidade Federal Rural do Rio de Janeiro. Antiga Rodovia Rio-São Paulo, km 47, \\ 23851-970 Seropédica, Rio de Janeiro, RJ, Brazil. E-mail: alexbioufrrj@hotmail.com; biancafterra@yahoo.com.br \\ ${ }^{2}$ Corresponding author. E-mail: gerson@ufrrj.br
}

\begin{abstract}
Changes in fish assemblage structure along a longitudinal gradient of the Paraíba do Sul River and Funil reservoir were studied to detect distribution patterns and the seasonal influence of the inflowing river. Fish were caught by gill nets in three zones (riverine, transition and lentic) during two seasons (dry and wet). A total of 3,721 individuals were captured, comprising five orders, 14 families, 27 genera and 33 species. Five species were non-native and amounted to $17.7 \%$ of the total number of individuals. The 10 most abundant species were used to assess spatial-temporal patterns. Plagioscion squamosissimus (Heckel, 1840), Oligosarcus hepsetus (Curvier, 1829) and Metynnis maculatus (Kner, 1858) were widely distributed in both seasons. Astyanax bimaculatus (Linnaeus, 1758), Cichla kelberi Kullander \& Ferreira, 2006 and Geophagus brasiliensis (Quoy \& Gaimard, 1824) had higher abundance in the dry season, occurring mainly in the lentic zone. By contrast, the benthopelagics Pimelodus maculatus La Cèpede, 1803 and Astyanax parahybae (Eigenmann, 1908) and the benthics Hoplosternum littorale (Hancock, 1828) and Hypostomus auroguttatus Kner, 1854 had higher abundance in the wet season, with the two first species occurring mainly in the riverine zone, and latter two species in the transition zone. The highest diversity for both seasons was recorded in the transition zone, which is an ecotone that allows the co-existence of both riverine and lentic species. A major shift in assemblage structure occurred along the longitudinal gradient due to changes in discharge of the inflowing river, with increased fish abundance in the riverine zone caused by increased habitat availability in wet season, and the reverse of this situation in the dry season.
\end{abstract}

KEY WORDS. Dam; fish diversity; Paraíba do Sul River; seasonality.

Water flow represents the main force behind freshwater ecosystems (Poff et al. 1997), determining the distribution, abundance, and diversity of stream and river organisms (Schlosser 1982, Poff \& Allan 1995, Ward et al. 1999, Nilsson \& SVEDMARK 2002). The movement of water across the landscape influences the ecology of rivers across a broad range of spatial and temporal scales (VAnNote et al. 1980, Poff et al. 1997, Sparks 1995). River flow strongly influences the ichthyofauna. By regulating the input of organic matter, it affects the phenology of reproduction and spawning behavior of local fish assemblages, and determines habitat diversification.

Despite the well-known importance of river flow, an increase in river damming that compromises freshwater systems has taken place around the world. This process, so intense and dramatic, results in the creation of a new ecosystem (BAXTER 1977) with its own ecological characteristics. The suppression of natural flow regimes has far-reaching impacts. It alters pristine hydrological dynamics, disturbs historical patterns of biological production, and changes the distribution of organisms in space and time (NILSSON et al. 2005). Seasonal variations in water level also have direct influences on the structure of species assemblages along the longitudinal gradient due to changes in water features (e.g. transparency and allochthonous material input), habitat availability (mainly in the riverine zone) and food resources. These new environmental conditions in impounded areas, which include increased water transparency, favor the colonization by opportunists (e.g. characins) and nonnative carnivores (e.g. cichlids) that make more intensive use of vision.

The Paraíba do Sul River is one of the most used lotic systems in Brazil. A series of dams have been built along the longitudinal axis of this river that crosses large urban-industrial centers (Araújo 1996, Bizerril 1999). Among these, the Funil reservoir stands as the largest impoundment for hydroelectric power generation in this river. Its basin has a longitudinal profile, following the river bed, and the river-reservoir gradient is characterised by three differentiated zones (riverine, transition and lentic). Below the dam, the water flow is regulated according to the requirements of the hydroelectric power plant. The stabilization of the natural flood pulse and the impairment of 
migratory routes for fish caused by the dam (absence of mechanism for upstream migrations) are among the main disturbances to the system downstream of the dam (Marengo \& Alves 2005). Other impairments present in this environment are increased nutrient concentrations and cyanobacterial blooms which have transformed this reservoir into a eutrophic system (Rocha et al. 2002) with high sedimentation, lack of riparian vegetation, uncontrolled introduction of species, and the absence of control or surveillance of fisheries.

The present study aimed to describe the patterns of diversity in the fish assemblage of the Paraíba do Sul River - Funil reservoir system along three zones (riverine, transition and lentic) and two seasons (dry and wet). To accomplish this, we attempted to establish correlations between environmental alterations caused by changes in discharge of the inflowing river and shifts in the structure of the fish assemblage.

\section{MATERIAL AND METHODS}

The Paraíba do Sul River is the largest fluvial drainage basin in the state of Rio de Janeiro. It flows through the three most economically important states in Brazil: São Paulo, Rio de Janeiro and Minas Gerais. This 1,100 km long river provides drinking water for domestic and public consumption, including irrigation, industrial self-supply systems, aquaculture and hydroelectric power generation (BRANCO et al. 2002). However, a growing increase in the discharge of pollutants, suspended solids and nutrients into the Paraíba do Sul, along with consecutive impoundments along its longitudinal axis have raised a series of environmental concerns.

The Funil reservoir $\left(22^{\circ} 30^{\prime}-22^{\circ} 40^{\prime} \mathrm{S}, 44^{\circ} 30^{\prime}-44^{\circ} 45^{\prime} \mathrm{W}\right)$, located at the middle portion of the Paraíba do Sul River (Fig. 1), started operating in 1969 under a concession of the Furnas Centrais Elétricas S.A. This $20 \mathrm{~km}$ long reservoir has a flooded area of approximately $40 \mathrm{~km}^{2}$ and a short retention time (1050 days), which results in great variations in water levels and substantial erosion of the banks. The main purposes of the Funil reservoir are to generate electricity and to reduce the frequency and intensity of floods in cities downstream.

Depending on the shape and area of a reservoir, a longitudinal hydrological gradient may develop from the dam (lentic zone) to upstream reaches (riverine zone), showing intermediate characteristics in middle stretches (transition zone), with lentic and lotic features (KImmel et al. 1990). These three zones are well defined in the Funil reservoir, and were chosen to assess the longitudinal gradient. The riverine zone is a typical lotic environment with faster water flow when compared with the other two zones. In the wet season, the water covers part of the riparian vegetation, increasing shelter availability and nutrient input. The transition zone is an ecotone between the riverine and lentic zones. It has a riprap (a structure made from a variety of rock types used to armor shorelines against scouring water or other kinds of erosion) that protects a nearby highway from flooding, besides increasing habitat heteroge-

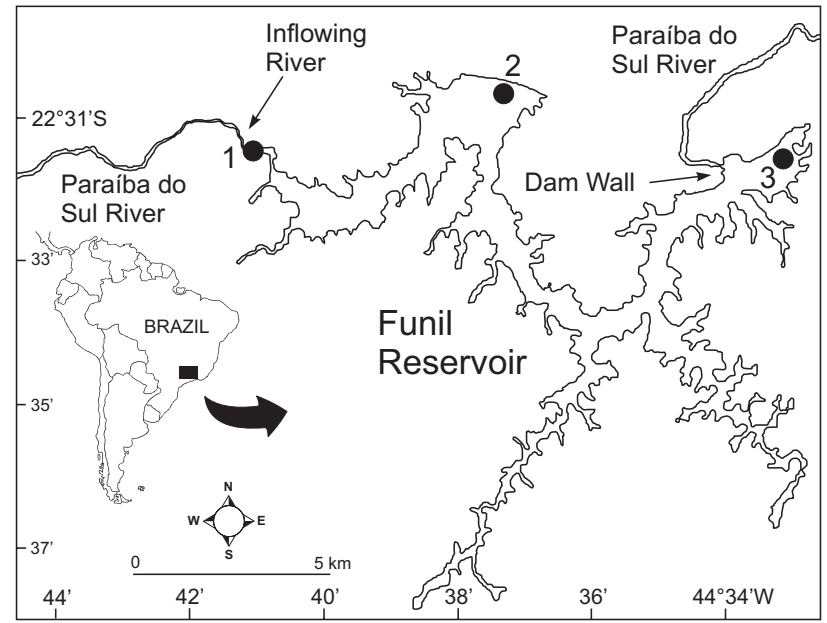

Figure 1. Studied area with indication of the sampled zones: riverine (1), transition (2) and lentic (3).

neity and bank stability. The lentic zone is deeper and more transparent than the other zones, having an extensive and unprotected shore area due to draw-down of the reservoir water.

Sampling was carried out monthly, between October 2006 to September 2007 (except May and July). In each zone, four sites were chosen randomly. Three gill nets $(50 \times 3 \mathrm{~m}$; stretch mesh 25, 50 and $75 \mathrm{~mm}$ ) were set up at sunset and retrieved in the following morning at each site. The sampling unit was defined as the sum of fish caught in the four sites.

The fish collected were fixed in formalin $10 \%$ for 48 hours and subsequently transferred to ethanol $70 \%$. Fish were indentified following the compilation of Fowler (1948, 1950, 1951, 1954) and Reis et al. (2003), or by consulting specialists and museum curators. Vouchers were deposited in the reference collection of the Laboratório de Ecologia de Peixes of the Universidade Federal Rural do Rio de Janeiro.

In order to investigate temporal variations in fish assemblage, we used the daily rainfall and flow data provided by the Furnas Centrais Elétricas S.A for the sample period. We considered the wet season as corresponding to the months with highest accumulated precipitation (October 2006 to February 2007), and the dry season as the months with lowest precipitation (March to September 2007) (Fig. 2).

Comparisons of mean number of individuals and species (richness), diversity, evenness and dominance were performed among zones and seasons by two-way analysis of variance and a post hoc Fisher LSD test. Diversity was estimated by the Shannon index (MagurRAN 1988). Evenness was calculated as Shannon diversity divided by the logarithm of number of species. The values of Dominance is given by the complement of the Simpson's index $(\mathrm{D}=1-\mathrm{S})$. These indices were analyzed using the statistical package PAST (Hammer et al. 2001). 


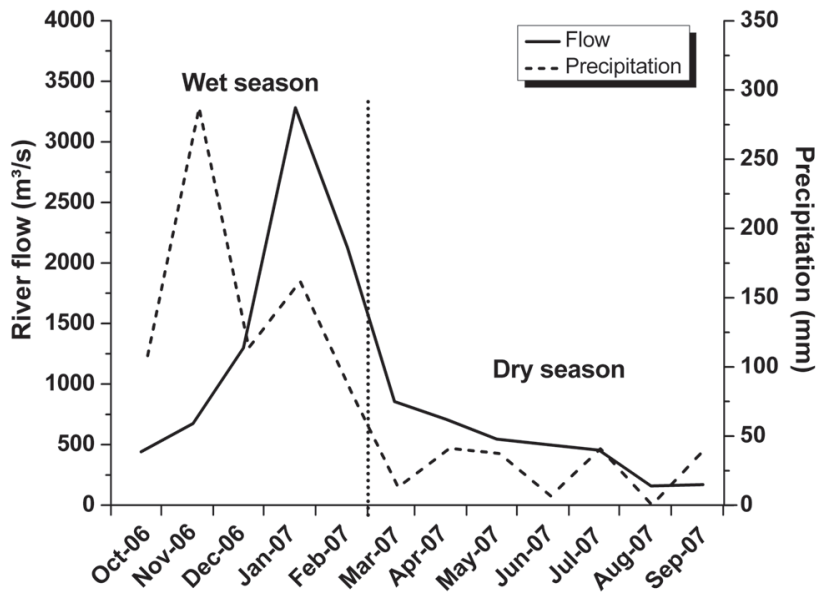

Figure 2. Monthly accumulated precipitation and flow during the sampling period.

We also compared abundance of the 10 most numerous species among zones and seasons by using the non-parametric Kruskal-Wallis test, followed by the multiple comparisons of the mean rank for all groups ( $\mathrm{p}<0.05)$.

\section{RESULTS}

A total of 3,712 individuals, comprising five orders, 14 families, 27 genera and 33 species were caught (Tab. I). Characiformes predominated with 15 species (45.5\%), followed by Siluriformes with nine $(27.3 \%)$ and Perciformes with six $(18.2 \%)$ species. Gymnotiformes and Symbranchiformes were represented by only two (6\%) and one (3\%) species, respectively. Characidae had the highest richness (8) comprising $24.3 \%$ of the total number of species, followed by Cichlidae and Loricariidae with four species each. Characidae was also the most abundant, contributing with $52.1 \%$ of total individuals and $20.2 \%$ of the total biomass.

The 10 most numerous species represented $88.7 \%$ of the total catch and $73 \%$ of total biomass, and were used to assess temporal and spatial patterns. The five most abundant species were, in decreasing order: Astyanax bimaculatus (Linnaeus, 1758), Pimelodus maculatus La Cèpede, 1803, Hoplosternum littorale (Hancock, 1828), Plagioscion squamosissimus (Heckel, 1840) and Metynnis maculatus (Kner, 1858). Collectively, they contributed to $74.9 \%$ of the total number of individuals and $56.4 \%$ of the total biomass. Eight species contributed to less than $0.1 \%$ of the total number of individuals and eight amounted less than $0.1 \%$ of total biomass (Tab. I).The species that most contributed to the biomass were P. maculatus, A. bimaculatus, $P$. squamosissimus, $H$. littorale and Hoplias malabaricus (Bloch, 1794).

Only five species - A. bimaculatus, P. maculatus, $P$. squamosissimus, Hypostomus auroguttatus Kner, 1854 and Oligosarcus hepsetus (Curvier, 1829) - were classified as frequent, occurring in more than $75 \%$ of the samples. Five non-native species - Cichla kelberi Kullander \& Ferreira, 2006, M. maculatus, P. squamosissimus, Oreochromis niloticus (Linnaeus, 1758) and Piaractus mesopotamicus (Holmberg, 1887) - were also collected, comprising $17.7 \%$ of the total number of individuals.

Plagioscion squamosissimus, O. hepsetus, and M. maculatus were widely distributed over the three zones during both seasons (Tab. II). By contrast, A. bimaculatus, C. kelberi and Geophagus brasiliensis (Quoy \& Gaimard, 1824) occurred mainly in the lentic zone during the dry season (Fig. 3 and Tab. II). In the wet season, P. maculatus and Astyanax parahybae (Eigenmann, 1908) were more abundant in the riverine zone, while $H$. littorale and $H$. auroguttatus predominated in the transition zone (Fig. 3 and Tab. II). Geophagus brasiliensis was the only species with restricted distribution in the reservoir zones (lentic and transition), peaking in the dry season.

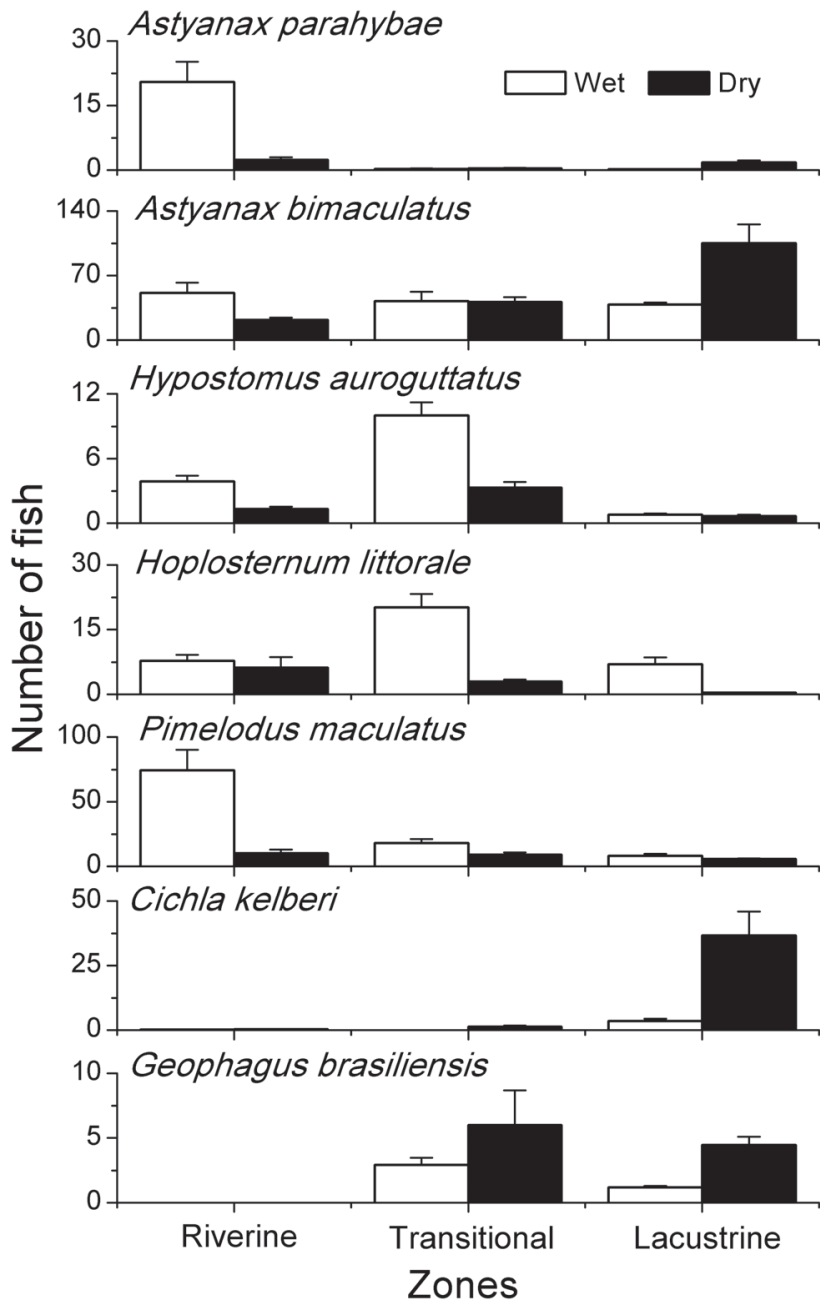

Figure 3. Average values and standard error (vertical lines) for fish species that differed significantly among zones and seasons. 
Table I. Number of specimens $(\mathrm{N})$, standard length range ( $\mathrm{SL}$, in $\mathrm{mm}$ ), total biomass ( $\mathrm{B}$, in $\mathrm{kg}$ ) and frequency of occurrence (FO) of the fish sampled in the Paraíba do Sul River - Funil reservoir system $\left({ }^{*}\right.$, non-native species). $S=$ species richness.

\begin{tabular}{|c|c|c|c|c|c|c|c|c|c|c|c|c|}
\hline \multirow{2}{*}{ Species } & \multicolumn{2}{|c|}{ Riverine $(S=23)$} & \multicolumn{2}{|c|}{ Transition $(S=28)$} & \multicolumn{2}{|c|}{ Lentic $(S=25)$} & \multirow[t]{2}{*}{ N } & \multirow[t]{2}{*}{$\% \mathrm{~N}$} & \multirow[t]{2}{*}{ B } & \multirow[t]{2}{*}{$\% B$} & \multirow[t]{2}{*}{$\%$ FO } & \multirow[t]{2}{*}{ SL } \\
\hline & $\mathrm{N}$ & B & $N$ & B & $N$ & B & & & & & & \\
\hline
\end{tabular}

\begin{tabular}{|c|c|c|c|c|c|c|c|c|c|c|c|c|}
\hline \multicolumn{13}{|l|}{ Characiformes } \\
\hline \multicolumn{13}{|l|}{ Anastomidae } \\
\hline Leporinus copelandii Steindachner, 1875 & 33 & 10.4 & 20 & 3.7 & 2 & 0.7 & 55 & 1.5 & 14.8 & 5.2 & 53.3 & $164-435$ \\
\hline Leporinus conirostris Steindachner, 1875 & 13 & 6.5 & 26 & 9.3 & 3 & 0.5 & 42 & 1.1 & 16.3 & 5.8 & 33.3 & $248-354$ \\
\hline Leporinus mormyrops Steindachner, 1875 & 1 & 0.1 & 3 & 0.1 & - & - & 4 & 0.1 & 0.2 & $<0.1$ & 6.7 & $160-185$ \\
\hline \multicolumn{13}{|l|}{ Characidae } \\
\hline Astyanax bimaculatus (Linnaeus, 1758) & 366 & 12.6 & 418 & 10.3 & 718 & 10.7 & 1501 & 40.4 & 33.6 & 11.8 & 96.7 & $89-149$ \\
\hline Astyanax parahybae (Eigenmann, 1908) & 114 & 4.5 & 4 & 0.2 & 10 & 0.2 & 128 & 3.4 & 4.9 & 1.7 & 43.3 & $90-140$ \\
\hline Astyanax sp. & - & - & - & - & 1 & 0.01 & 1 & $<0.1$ & 0.0 & $<0.1$ & 3.3 & 120 \\
\hline Brycon insignis Steindachner, 1877 & 1 & 0.1 & 1 & 0.1 & - & - & 2 & $<0.1$ & 0.2 & $<0.1$ & 6.7 & $180-190$ \\
\hline Probolodus heterostomus Eigenmann, 1911 & - & - & 1 & 0.2 & 18 & 0.0 & 19 & 0.5 & 0.2 & $<0.1$ & 6.7 & $107-126$ \\
\hline Oligosarcus hepsetus (Curvier, 1829) & 24 & 3.7 & 16 & 2.8 & 22 & 3.8 & 63 & 1.7 & 10.3 & 3.6 & 76.7 & $149-303$ \\
\hline Metynnis maculatus (Kner, 1858)* & 11 & 0.4 & 190 & 6.7 & 16 & 0.6 & 216 & 5.8 & 7.7 & 2.7 & 40.0 & $118-149$ \\
\hline Piaractus mesopotamicus (Holmberg, 1887)* & 3 & 0.1 & - & - & 1 & 0.0 & 4 & 0.1 & 0.2 & $<0.1$ & 6.7 & $100-122$ \\
\hline \multicolumn{13}{|l|}{ Crenuchidae } \\
\hline Characidium lauroi Travassos, 1949 & 1 & - & 2 & 0.0 & - & - & 3 & $<0.1$ & 0.0 & $<0.1$ & 6.7 & $204-209$ \\
\hline \multicolumn{13}{|l|}{ Curimatidae } \\
\hline Cyphocarax gilbert (Quoy \& Gaimard, 1824) & 18 & 3.0 & 5 & 0.5 & - & - & 23 & 0.6 & 3.5 & 1.3 & 10 & $180-230$ \\
\hline \multicolumn{13}{|l|}{ Erythrinidae } \\
\hline Hoplias malabaricus (Bloch, 1794) & 18 & 6.2 & 19 & 8.7 & 8 & 2.6 & 45 & 1.2 & 17.5 & 6.2 & 73.3 & $150-417$ \\
\hline Hoplerythrinus unitaeniatus (Agassiz, 1829) & 3 & 0.4 & 5 & 1.0 & 1 & 0.1 & 9 & 0.2 & 1.7 & 0.6 & 20.0 & $171-220$ \\
\hline \multicolumn{13}{|l|}{ Siluriformes } \\
\hline \multicolumn{13}{|l|}{ Callichthyidae } \\
\hline Callichthys callichthys (Linnaeus, 1758) & 16 & 1.0 & 8 & 1.2 & 2 & 0.1 & 25 & 0.7 & 2.4 & 0.9 & 13.3 & $125-172$ \\
\hline Hoplosternum littorale (Hancock, 1828) & 70 & 8.0 & 115 & 14.5 & 37 & 5.1 & 222 & 6.0 & 27.6 & 9.7 & 70.0 & $127-210$ \\
\hline \multicolumn{13}{|l|}{ Loricariidae } \\
\hline Hypostomus affinis (Steindachner, 1877) & 21 & 4.8 & 17 & 2.8 & 7 & 1.2 & 45 & 1.2 & 8.8 & 3.1 & 46.7 & $248-354$ \\
\hline Hypostomus auroguttatus Kner, 1854 & 26 & 5.8 & 66 & 10.1 & 7 & 1.4 & 100 & 2.7 & 17.3 & 6.1 & 83.3 & $190-354$ \\
\hline Rineloricaria sp. & - & - & 2 & 0.0 & 1 & 0.0 & 3 & $<0.1$ & 0.1 & 0.2 & 6.7 & $135-160$ \\
\hline Rhinelepis aspera Spix \& Agassiz, 1829 & - & - & 5 & 1.0 & - & - & 5 & 0.1 & 1.0 & 0.6 & 6.7 & $249-275$ \\
\hline \multicolumn{13}{|l|}{ Pimelodidae } \\
\hline Pimelodus maculatus La Cèpede, 1803 & 422 & 33.2 & 135 & 15.8 & 70 & 9.5 & 627 & 16.9 & 58.5 & 20.7 & 90.0 & $98-350$ \\
\hline Pimelodus fur (Lütken, 1874) & - & - & - & - & 2 & 0.1 & 2 & $<0.1$ & 0.1 & $<0.1$ & 6.7 & $123-149$ \\
\hline \multicolumn{13}{|l|}{ Auchenipteridae } \\
\hline Glanidium albescens Lütken, 1874 & 1 & 0.4 & - & - & - & - & 1 & $<0.1$ & 0.4 & 0.1 & 3.3 & 145 \\
\hline \multicolumn{13}{|l|}{ Gymnotiformes } \\
\hline \multicolumn{13}{|l|}{ Gymnotidae } \\
\hline Gymnotus carapo Linnaeus, 1758 & 10 & 0.5 & 26 & 2.0 & 1 & 0.1 & 37 & 1.0 & 2.5 & 0.9 & 40.0 & $237-341$ \\
\hline
\end{tabular}


Table I. Continued.

\begin{tabular}{|c|c|c|c|c|c|c|c|c|c|c|c|c|}
\hline \multirow{2}{*}{ Species } & \multicolumn{2}{|c|}{ Riverine $(S=23)$} & \multicolumn{2}{|c|}{ Transition $(S=28)$} & \multicolumn{2}{|c|}{ Lentic $(S=25)$} & \multirow[t]{2}{*}{$N$} & \multirow[t]{2}{*}{$\% \mathrm{~N}$} & \multirow[t]{2}{*}{ B } & \multirow[t]{2}{*}{$\% \mathrm{~B}$} & \multirow[t]{2}{*}{$\% \mathrm{FO}$} & \multirow[t]{2}{*}{ SL } \\
\hline & N & B & $\mathrm{N}$ & B & $N$ & B & & & & & & \\
\hline \multicolumn{13}{|l|}{ Sternopygidae } \\
\hline Eigenmannia virescens (Valenciennes, 1842) & 7 & 0.3 & 1 & 0.0 & - & - & 8 & 0.2 & 0.4 & 0.1 & 10.0 & $209-300$ \\
\hline \multicolumn{13}{|l|}{ Symbranchiformes } \\
\hline \multicolumn{13}{|l|}{ Synbranchidae } \\
\hline Synbranchus marmoratus Bloch, 1795 & - & - & - & - & 1 & 0.1 & 1 & $<0.1$ & 0.1 & $<0.1$ & 3.3 & 415 \\
\hline \multicolumn{13}{|l|}{ Perciformes } \\
\hline \multicolumn{13}{|l|}{ Sciaenidae } \\
\hline Pachyurus adspersus Steindachner, 1879 & 2 & 0.1 & 2 & 0.0 & 9 & 1.6 & 13 & 0.4 & 1.8 & 0.6 & 20.0 & $215-252$ \\
\hline Plagioscion squamosissimus (Heckel, 1840)* & 77 & 9.8 & 70 & 14.3 & 69 & 8.0 & 217 & 5.8 & 32.1 & 11.3 & 86.7 & $105-360$ \\
\hline \multicolumn{13}{|l|}{ Cichlidae } \\
\hline Cichla kelberi Kullander \& Ferreira, 2006 * & 3 & 0.4 & 7 & 0.7 & 201 & 7.8 & 211 & 5.7 & 9.0 & 3.2 & 46.7 & $110-271$ \\
\hline Crenicichla lacustris (Castelnau, 1855) & - & - & 1 & 0.3 & - & - & 1 & $<0.1$ & 0.3 & 0.1 & 3.3 & 290 \\
\hline $\begin{array}{l}\text { Geophagus brasiliensis (Quoy \& Gaimard, } \\
\text { 1824) }\end{array}$ & - & - & 45 & 4.3 & 28 & 2.8 & 73 & 2.0 & 7.1 & 2.5 & 50.0 & $139-228$ \\
\hline Oreochromis niloticus (Linnaeus, 1758)* & - & - & 3 & 0.2 & 5 & 0.9 & 8 & 0.2 & 1.2 & 0.4 & 20.0 & $230-316$ \\
\hline Total & 1261 & 112.7 & 1211 & 111.5 & 1240 & 58.9 & 3712 & 100.0 & 283.0 & 100.0 & & \\
\hline
\end{tabular}

Table II. Results of Kruskall-Wallis (H) comparisons for numerical abundance of the 10 most numerous fish species among zones: (RZ) riverine, (TZ) transition, (LZ) lentic, for each season. (Post-hoc) Test for multiple comparisons of the mean rank for all groups; (n.s.) no significant; $\left(^{*}\right)$ significant $(\mathrm{p}<0.05) ;\left(^{* *}\right)$ highly significant $(\mathrm{p}<0.01)$.

\begin{tabular}{|c|c|c|c|c|}
\hline \multirow{2}{*}{ Species } & \multicolumn{2}{|c|}{ Wet season } & \multicolumn{2}{|c|}{ Dry season } \\
\hline & $\mathrm{H}$ & Post-hoc & $\mathrm{H}$ & Post-hoc \\
\hline Astyanax bimaculatus & n.s & - & $6,40^{\star \star}$ & $\mathrm{LZ}>\mathrm{RZ}$ \\
\hline Astyanax parahybae & $18,46^{\star *}$ & $\mathrm{RZ}>\mathrm{TZ}$ e $\mathrm{LZ}$ & n.s & - \\
\hline Cichla kelberi & n.s & - & $16,48^{* *}$ & $\mathrm{LZ}>\mathrm{RZ}$ \\
\hline Geophagus brasiliensis & n.s & - & $19,67^{* *}$ & $\mathrm{LZ}>\mathrm{RZ}$ \\
\hline Hypostomus auroguttatus & $15,69^{* *}$ & $\mathrm{TZ}>\mathrm{LZ}$ & n.s & - \\
\hline Hoplosternum littorale & $8,45^{*}$ & $\mathrm{TZ}>\mathrm{LZ}$ & n.s & - \\
\hline Metynnis maculatus & n.s & - & n.s & - \\
\hline Oligosarcus hepsetus & n.s & - & n.s & - \\
\hline Pimelodus maculatus & $13,66^{* *}$ & $\mathrm{RZ}>\mathrm{LZ}$ & n.s & - \\
\hline Plagioscion squamosissimus & n.s & - & n.s & - \\
\hline
\end{tabular}

In the riverine zone the number of species and the number of individuals were significantly higher $(\mathrm{p}<0.05)$ in the wet season, when compared with the dry season (Fig. 4 and Tab. III). In the remaining zones there was no significant difference in these parameters between seasons, although the number of individuals was higher in the transition zone in the wet season and in the lentic zone in the dry season.

The Shannon diversity and Dominance had an inverse pattern. The first was higher in the wet season, and the latter in the dry season across all zones (Fig. 4 and Tab. III). The Shannon diversity was comparatively higher in the transition zone in both seasons, while the Dominance was higher in the lentic zone.

The Evenness differed significantly $(p<0.05)$ among the zones during the dry season, being higher in the riverine zone and lower in the lentic zone. During the wet season there were no significant differences among the zones (Fig. 4 and Tab. III). 

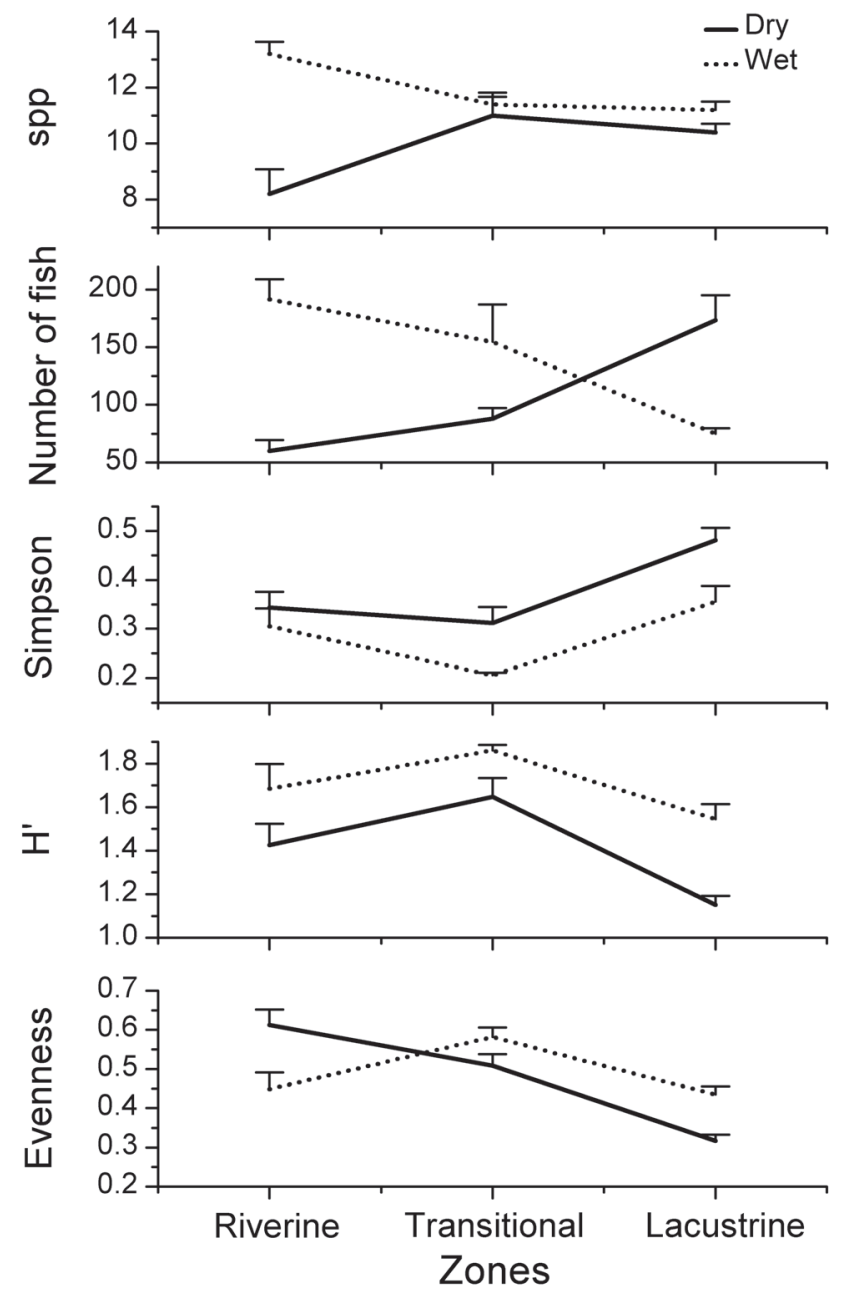

Figure 4. Average values and standard error (vertical lines) of richness (spp), number of fish, Dominance, Shannon diversity $\left(\mathrm{H}^{\prime}\right)$ and Evenness by zones and seasons.

\section{DISCUSSION}

A major difference in the structure of the fish assemblage was detected along the longitudinal stretches of the Paraíba do Sul - Funil reservoir system, featuring a more abundant and rich assemblage in the riverine zone during the wet season, and the opposite situation in the dry season. The pattern found in the wet season is probably a result of increased habitat availability and higher amounts of allochthonous material brought into the river. Flooding brings allochthonous food resources to fish, creating a greater abundance and diversity (HENDERSON 1990) of food that reduces competition for this resource. Furthermore, fish species tend to remain in environments that maintain the original fluvial characteristics or in those with great habitat heterogeneity, i.e., tributaries and lotic stretches upstream (Agostinho et al. 2007). In our data, the highest richness found in the riverine zone during the wet season confirms this trend. Generally, the biological rhythm of most tropical freshwater fish is synchronic with the flood pulse (LOwE-McCONNEL 1999), which coincides with higher temperatures and precipitation (Menezes et al. 1998). Thus, it was expected that the river upstream of the reservoir would have increased number of individuals and species during the wet season.

On the other hand, the droughts characteristic of the dry season cause a decrease in water levels and abundance of allochthonous material. This tends to restrict upstream habitats. During droughts, the lentic zone could be used by the ichthyofauna as refuge, since it provides more environmentally stable conditions due to greater depth, and consequently, greater water volume. This hypothesis is supported by the fact that species that are more frequent in the dry season, such as the cichlids C. kelberi and G. brasiliensis, and the characin A. bimaculatus, were more abundant in this zone. Cichlids species are exceptional because they have well developed vision (GoldsteIn 1973) and can take advantage of the increased transparency of lentic zones to chase their prey. Additionally, species such as G. brasiliensis and C. kelberi benefit from drought conditions, where the input of allochthonous material from upper stretches is reduced. Sediments in suspension increase the attenuation of light in the water column (KIRK 1983), reducing the penetration and extension of visual species that mainly use this sense to forage (DAviEs \& SMITH 2001).

Previous studies have found higher fish diversity in the upstream reaches of reservoirs, where the water flow is faster, than in the lentic zone closer to the dam (Hoffmann et al. 2005, Britto \& Carvalho 2006, Petesse et al. 2007). By contrast, in this study the transition zone had the highest Shannon diversity and number of recorded species. As pointed out by Oliverra et al. (2003) lotic and lentic species may co-exist and use this habitat temporally, thus increasing local species richness and diversity, and we postulate that this might have been the case in our study. Ecotones play an important role in fish diversity (KOLASA \& ZALEWSKI 1995) and community structure (Willis \& MAGnuson 2000) in reservoirs, insofar as they usually have specific features such as physical shelters, well developed riparian vegetation and spawning areas.

It is recognized that reservoirs typically support fewer fish species than their associated rivers, often as a result of largescale changes in temperature, turbidity, flow, allochthonous nutrient inputs, and availability of food resource regimes (WILLIAMs et al. 1998). However, another factor that greatly contributes to a reduction in biodiversity is the barrier created by the river damming, which increases the probability of regional extinction of rheophilic species. Only 33 species were recorded in this study, indicating comparatively low fish richness when compared with other surveys carried out in other stretches downstream in the Paraíba do Sul River. Araújo et al (2001) 
Table III. Two-way analysis of variance comparisons for number of species, individuals, Dominance, Shannon and Evenness indices among zones: (RZ) riverine zone, (TZ) transition zone, (LZ) lentic zone, and seasons: (w) wet, (d) dry. (FLSD) Test of Fisher, (n.s.) no significant, $\left.{ }^{*}\right)$ significant $(p<0.05)$.

\begin{tabular}{|c|c|c|c|c|c|c|c|c|c|c|}
\hline \multirow{2}{*}{ Effect } & \multicolumn{2}{|c|}{ Species } & \multicolumn{2}{|c|}{ Number of fish } & \multicolumn{2}{|c|}{ Dominance } & \multicolumn{2}{|c|}{ Shannon } & \multicolumn{2}{|c|}{ Evenness } \\
\hline & $\mathrm{F}$ & FLSD & $\mathrm{F}$ & FLSD & $\mathrm{F}$ & FLSD & $\mathrm{F}$ & FLSD & $\mathrm{F}$ & FLSD \\
\hline Season (S) & $4.35^{\star}$ & $\mathrm{RZw}>\mathrm{LZd}$ & $4.21^{*}$ & $\mathrm{RZw}>\mathrm{LZd}$ & n.s. & - & n.s. & - & n.s. & - \\
\hline Zone (Z) & n.s. & - & n.s. & - & n.s. & - & n.s. & - & $3.93^{*}$ & $\mathrm{RZd}>\mathrm{LZd}$ \\
\hline Interaction S vs. Z & n.s. & - & n.s. & - & n.s. & - & n.s. & - & n.s. & - \\
\hline
\end{tabular}

recorded 52 species in the main channel, in a stretch of approximately $50 \mathrm{~km}$ (Barra Mansa to Barra do Piraí). Araújo \& NUNAN (2005) recorded 61 species in a stretch of $112 \mathrm{~km}$ situated between the Funil and Santa Cecília (Barra do Piraí) dams. In this study, the low number of species recorded when compared with downstream stretches is an indication that the Funil dam is limiting the upstream richness, a clear result of the absence of a mechanism that allows fish migration. However, comparisons of the number of species between different sites should be analyzed with caution, because the results may be dependent on the area sampled and the effort applied.

Among the abundant species, G. brasiliensis was the only species captured only in reservoir zones (transition and lentic), indicating that this species is very suitable for lentic environments. It has an extraordinary capacity to adapt to lentic conditions, being is one of the most common species in Brazil, and abundant in lakes and reservoirs of the State of Rio de Janeiro (Bizerril 1999). The detritivorous-iliophagous (MeschiantTi 1995) or omnivorous (Aguiaro \& Caramashi 1998) feeding habits of $G$. brasiliensis favor the success of this species in reservoirs. According to Lowe-McConnell (1999), abrupt changes in habitat have a particularly intense effect on the availability of food, favoring generalist species because they have great trophic plasticity.

The practice of introducing non-native species into recently built reservoirs, often harmful to the native population structure, is common for a variety of reasons (McDowall 1968), e.g. sport fishing and fish farming. Some fish populations decline due to overfishing, environmental changes, and competition with non-native species (Lowe-McConNell 1990). Cichla kelberi is a native species from the Araguaia River drainage and lower Tocantins River, with great predation ability. The colonization success of this species depends on the presence of a broad littoral zone, since shallow and marginal areas are used to spawn (Williams et al. 1998). This condition can be found in the lentic zone, especially during the dry season, when this species was captured in abundance. Plagioscon squamosissimus is another native species from the Amazon basin (BENNEMANn et al. 2006). This species produces small, pelagic and buoyant eggs spawned in several batches during the reproductive season (AgostinHo et al. 1999), using this reproductive strategy for colonization and spread over wide areas in reservoirs.
Seasonal and spatial differences in the occurrence of $A$. bimaculatus and $A$. parahybae may be associated with mechanisms to avoid competitive exclusion by these two closely-related species. Gomiero \& Braga (2005), after studying species of Astyanax Baird and Girard, 1854, suggested that the exploitation of different microhabitats, in combination with diet, indicate that food resources are shared without competition. According to Benedito-Cecílio \& Agostinho (1997), small species, such as some characins, can be classified as opportunistic because of their high reproductive potential, trophic plasticity, low longevity and tolerance to environmental constraints. These species generally predominate in lentic environments (CAStro \& Arcifa 1987, Smith et al. 2003), especially in littoral areas, and are adapted to live in these habitats modified by humans (Sмiтн et al. 2003, Agostinho et al. 2007). A clear spatial segregation found in this study suggests that $A$. bimaculatus is more adapted to lentic systems, with peaks in the dry season, while $A$. parahybae is more adapted to lotic systems.

The comparatively highly structured habitat of the transition zone, comprised of stones and rocks of different sizes used in the riprap may be associated with the high abundance of $H$. auroguttatus. In general, loricarids are present in places where stones and rocks predominate. CARAMASCHI (1994) recorded that Hypostomus spp. are associated with imbedded rock formation and runs. Therefore, both the physical habitat and the typical increase of water flow during the wet season contribute to higher occurrence of $H$. auroguttatus in the transition zone.

Resilience is an important factor determining the permanence of a species in environments that are susceptible to changes, such as reservoirs. Hoplosternum littorale, typical of muddy habitats, has several physiological adaptations that enable individuals to tolerate impacted environments, such as the ability to breathe atmospheric oxygen (CARTER \& BeAdLE 1931) and blood cell modifications that ensure greater efficiency during hypoxia (AcuÑa \& SANZ 1992). These characteristics favor the success of this species in reservoir colonization. The distribution pattern revealed for this species in our work is consistent with the findings of TeixeIra et al. (2005), who found that $H$. littorale is abundant at the middle-upper stretch of the Paraíba do Sul River during the flood period.

Pimelodus maculatus is known as a migratory species that needs fewer free river stretches to spawn than other Neotropi- 
cal migrants (AgostinHo et al. 2003). This species was widely distributed during the dry season. By contrast, it was found mainly in the riverine zone in the wet season, possibly for reproductive purposes. It is widely known that reproduction of most species, particularly migrant species, coincides with the rainy season and high temperatures (Lowe-McConnell 1975, Santos \& Ferreira 1987, Vazzoler et al. 1997). In spite of the river obliteration, this species has high resilience, since it was one of the most abundant and widely distributed fish in the Paraíba do Sul - Funil reservoir system.

\section{LITERATURE CITED}

Acuña, M.L. \& SANZ, M. 1992. Estudio preliminar sobre las variaciones de la citomorfologia sanguinea del pez de agua dulce Hoplosternum littorale sometido a hipoxia experimental. Acta Biologica Venezolana 13: 53-63.

Agostinho, A.A.; L.E. Miranda; L.M. Bini; L.C. Gomes; S.M. Thomaz $\&$ H.I. SUZUKI. 1999. Patterns of colonization in neotropical reservoirs, and prognoses on aging, p. 227-265. In: J.G. TundisI \& M. StRASKRABA (Eds). Theoretical reservoir ecology and its applications. Leiden, Backhuys Publishers, 592p.

Agostinho, A.A.; L.C. Gomes; H.I. Suzuki \& H.F. Júlio JR. 2003. Migratory fishes of the Upper Paraná river basin, Brazil. In: J. Carolsfeld; B. Hervey; C. Ross \& A. Baer (Eds). Migratory fishes of South America: biology, fisheries and conservation status. Ottawa, World Fisheries Trust, International Bank for Reconstruction and Development, The World Bank, 372p.

Agostinho, A.A.; L.C. Gomes \& F.M. Pelicice. 2007. Ecologia e manejo de recursos pesqueiros em reservatórios do Brasil. Maringá, EDUEM, 501p.

Aguiaro, T. \& E.P. Caramaschi. 1998. Trophic guilds in fish assemblages is three coastal lagoons of Rio de Janeiro State (Brazil). Verhandlungen des Internationalen Verein Limnologie 26: 2166-2169.

Araújo, F.G. 1996. Composição e estrutura da comunidade de peixes do médio e baixo rio Paraíba do Sul, RJ. Revista Brasileira de Biologia 56 (1): 111-126.

Araújo, F.G.; I. Fichberg; B.C.T. Pinto \& M.G. Peixoto. 2001. Variações espaciais na assembléia de peixes no rio Paraíba do Sul (Barra Mansa, Barra do Piraí), Rio de Janeiro, Brasil. Revista Brasileira de Zoologia 18 (2): 483-492.

Araújo, J.R.S. \& G.W. Nunan. 2005. Ictiofauna do rio Paraíba do Sul: danos ambientais e sociais causados por barragens, hidrelétricas e poluição no trecho fluminense. Rio de Janeiro, CPDMA-ALERJ, 59p. Available online at: http:// www.minc.com.br/mandato/meioambi/relatoriopeixesbarragens. Ipdf [Accessed: 1.IV.2010].

BAXter, R.M. 1977. Environmental effects of dams and impoundments. Annual Review of Ecology and Systematics 8: 255-283.

Benedito-Cecílio, E. \& A.A. Agostinho. 1997. Estrutura das populações de peixes no reservatório de Segredo, p. 113-135.
In: A.A. Agostinho \& L.C. Gomes (Eds). Reservatório de Segredo: bases ecológicas para o manejo. Maringá, EDUEM, 387p.

Bennemann, S.T.; L.G. Capra; W. Galves \& O.A. Shibatta. 2006. Dinâmica trófica de Plagioscion squamosissimus (Perciformes, Sciaenidae) em trechos de influência da represa Capivara (rios Paranapanema e Tibagi). Iheringia, Série Zoologia, 96 (1):115-119.

BizerRIL, C.R.S.F. 1999. A ictiofauna da bacia do rio Paraíba do Sul: biodiversidade e padrões biogeográficos. Brazilian Archives of Biology and Technology 42 (2): 233-250.

Branco, C.W.C.; M.I.A. Rocha; G.F.S. Pinto; G.A. Gômara \& R.D. FiLIPPo. 2002. Limnological features of Funil Reservoir (R.J., Brazil) and indicator properties of rotifers and cladocerans of the zooplankton community. Lakes \& Reservoirs: Research and Management 7: 87-92.

Britto, S.G.C. \& E.D. Carvalho. 2006. Ecological attributes of fish fauna in the Taquaruçu reservoir, Paranapanema river (upper Paraná, Brazil): composition and spatial distribution. Acta Limnologica Brasiliensis 18 (4): 377-388.

Caramaschi, E.P. 1994. Aspectos da distribuição dos peixes de água doce. In: Comase. Seminário sobre fauna aquática e o setor elétrico brasileiro. Rio de Janeiro, Reuniões Temáticas Preparatórias, Caderno 1, p. 18-22.

Carter, G.S. \& L.C. Beadle. 1931. The fauna of the swamps of the Paraguayan Chaco in relation to its environment. II. Respiratory adaptations in the fishes. Journal of the Linnean Society (Zoology) 37: 327-368.

Castro, R.M.C. \& M.S. Arcifa. 1987. Comunidades de peixes de reservatórios no sul do Brasil. Revista Brasileira de Biologia 47 (4): 493-500.

Davies, R.J.C. \& D.G. SMith. 2001. Turbidity, suspended sediment, and water clarity: A review. Journal of the American Water Resources Association 37 (5): 1085-1101.

Fowler, H.W. 1948. Os peixes de água doce do Brasil. Arquivos. Zoologia do Estado de São Paulo 6: 1-204.

Fowler, H.W. 1950. Os peixes de água doce do Brasil. Arquivos. Zoologia do Estado de São Paulo 6: 205-404.

Fowler, H.W. 1951. Os peixes de água doce do Brasil. Arquivos. Zoologia do Estado de São Paulo 6: 405-625.

Fowler, H.W. 1954. Os peixes de água doce do Brasil. Arquivos. Zoologia do Estado de São Paulo 6: 1-400.

Goldstein, R.J. 1973. Cichlids of the world. New Jersey, T.F.H. Publications, 382p.

Gomiero, L.M. \& F.M.S. Braga. 2005. Uso do grau de preferência alimentar para a caracterização da alimentação de peixes na APA de São Pedro e Analândia. Acta Scientiarum Biological Sciences 27 (3): 265-279.

Hammer, Ø; D.A.T. Harper. \& P.D. Ryan. 2001. PAST: paleontological statistics software package for education and data analysis. Palaeontologia Electronica 4 (1). Available online at: http://palaeo-electronica.org/2001_1/past/issue1_01.htm [Accessed: 11.X.2010]. 
Henderson, P.A. 1990. Fish of the Amazonian Igapó: stability and conservation in a high diversity-low biomass system. Journal of Fish Biology 37 (Suppl. A): 61-66.

Hoffmann, A.C.; M.L. Orsi. \& O.A. Shibatta. 2005. Diversidade de peixes do reservatório da UHE Escola Engenharia Mackenzie (Capivara), rio Paranapanema, bacia do alto rio Paraná, Brasil, e a importância dos grandes tributários na sua manutenção. Iheringia, Série Zoologia, 95 (3): 319-325.

Kimmel, B.L.; O.T. Lind. \& L.J. Paulson. 1990. Reservoir primary production. In: K.W. Thornton; B.L. Kimmel \& F.E. PAYNe (Eds). Reservoir limnology: ecological perspectives. New York, J. Wiley and Sons, 246p.

KIRK, J.T.O. 1983. Light and photosynthesis in aquatic ecosystems. Cambridge, Cambridge University Press, 401p.

Kolasa, J. \& M. Zalewski. 1995. Notes on ecotone attributes and functions. Hydrobiologia 303: 1-7.

Lowe-McConnell, R.H. 1975. Fish Communities in tropical Freshwaters: Their Distribution, Ecology and Evolution. London, Longman, 337p.

Lowe-McConnelL, R.H. 1990. Summary address: rare fish, problems, progress and prospects for conservation. Journal of Fish Biology 37 (A): 263-269.

Lowe-McConnell, R.H. 1999. Estudos ecológicos de comunidades de peixes tropicais. São Paulo, EDUSP, 534p.

MagurRam, A.E. 1988. Ecological diversity and its measurements. London, Croom Helm, 179p.

Marengo, J.A. \& L.M. Alves. 2005. Tendências hidrológicas da bacia do rio Paraíba do Sul. Revista Brasileira de Meteorologia 20: 215-226.

MCDOWALL, R.M. 1968. Interactions of the native and alien faunas of New Zealand and the problem of fish introductions. Transactions of American Fisheries Society 97 (1): 1-11.

Menezes, M.S.; J.M.R. Aranha \& E.P. Caramaschi. 1998. Ocorrência e aspectos da biologia reprodutiva de Harttia loricariformis (Loricariinae) no trecho inferior do rio Paraíba do Sul. (Rio de Janeiro, Brasil). Acta Biológica Paranaense 27 (1-4): 15-26.

Meschiatti, A. J. 1995. Alimentação da comunidade de peixes de uma lagoa marginal do rio Mogi-Guaçu, SP. Acta Limnologica Brasiliensia 7: 115-137.

Nilsson, C. \& M. Svedmark. 2002. Basic principles and ecological consequences of changing water regimes: riparian plant communities. Environmental Management 30: 468-480.

Nilsson, C.; C.A. Reidy; M. Dynesius \& C. Revenga. 2005. Fragmentation and flow regulation of the world's large river systems. Science 308: 405-408.

Oliveira, E.F.; E. Goulart \& C.V. Minte-Vera. 2003. Patterns of dominance and rarity of fish assemblage along spatial gradients in the Itaipu reservoir, Paraná, Brazil. Acta Scientiarum Biological Sciences 25 (1): 71-78.

Petesse, M.L.; J.M. Petrere \& R.J. Spigolon. 2007. Adaptation of Reservoir Fish Assemblage Index (RFAI) for assessing the Barra Bonita reservoir (São Paulo, Brazil). River Research and Applications 23: 595-612.
PofF, N.L. \& J.D. Allan. 1995. Functional organization of stream fish assemblages in relation to hydrological variability. Ecology 76: 606-627.

Poff, N.L.; J.D. Allan; M.B. Bain; J.R. KarR; K.L. Prestegaard; B.D. Richter; R.E. Sparks \& J.C. Stromberg. 1997. The natural flow regime. BioScience 47 (11): 769-784.

Reis, R.E.; S.O. Kullander \& C.J. Ferraris Jr. 2003. Check list of the freshwater fishes of South and Central America. Porto Alegre, EDIPUCRS, 742p.

Rocha M.I.A.; C.W.C. Branco; G.F. SAmpaio \& R. De Filippo. 2002. Spatial and temporal variation of limnological features, Microcystis aeruginosa and zooplankton in a eutrophic reservoir (Funil Reservoir, Rio de Janeiro). Acta Limnologica Brasiliensia 14: 73-86.

Santos, G.M. \& E.J.G. Ferreira. 1987. Peixes da Bacia Amazônica. In: R.H. LowE-McConnell (Ed.). Estudos ecológicos de comunidade de peixes tropicais. São Paulo, EDUSP, 534p.

SCHLOSSER, I.J. 1982. Fish community structure and function along two habitat gradients in a headwater stream. Ecological Monographs 52: 395-414.

Smith, W.S.; C.C.G.F. Pereira; E.L.G. Espíndola \& O. Rocha. 2003. A importância da zona litoral para a disponibilidade de recursos alimentares à comunidade de peixes. In: R. Henry (Ed.) Ecótonos nas interfaces dos ecossistemas aquáticos. São Carlos, RIMA, 360p.

SPARKS, R.E. 1995. Need for ecosystem management of large rivers and floodplains. BioScience 45: 168-182.

Teixeira, T.P.; B.C.T. Pinto; B.F. Terra; E.O. Estiliano; D. Gracia \& F.G. Araújo. 2005. Diversidade das assembléias de peixes nas quatro unidades geográficas do rio Paraíba do Sul. Iheringia, Série Zoologia, 95 (4): 347-357.

Vannote R.L.; G.W. Minshall; K.W. Cummins; J.R. Sedell \& C.E. Cushing. 1980. The river continuum concept. Canadian Journal of Fisheries and Aquatic Sciences 37: 130-137.

Vazzoler, A.E.A.M.; M.A.P. Lizama \& P. InADA. 1997. Influências ambientais sobre a sazonalidade reprodutiva. In: A.E.A.M. Vazzoler; A.A. Agostinho \& N.S. Hahn (Eds). A Planície de Inundação do Alto Rio Paraná. Maringá, EDUEM, 460p.

WARD, J.V.; K. Tockner \& F. Schiemer. 1999. Biodiversity of floodplain ecosystems: Ecotones and connectivity. Regulated Rivers: Research and Management 15: 125-139.

Williams, J.D.; K.O. Winemiller; D.C. Taphorn \& L. Balbas. 1998. Ecology and status of piscivores in Guri, an oligotrophic tropical reservoir. North American Journal of Fisheries Management 18: 274-285.

Willis, T.V. \& J.J. Magnuson. 2000. Patterns in fish species composition across the interface between streams and lakes. Canadian Journal of Fisheries and Aquatic Sciencies 57: 1042-1052.

Submitted: 24.XI.2009; Accepted: 28.VIII.2010. Editorial responsibility: Rosana Mazzoni 